\title{
Economics
}

2015; 4(6): 98-105

Published online September 23, 2015 (http://www.sciencepublishinggroup.com/j/eco)

doi: $10.11648 /$ j.eco.20150406.11

\section{Transmission Mechanism from Money Supply to Inflation in Nigeria}

\author{
Mathias A. Chuba \\ Department of Economics, Faculty of Social Sciences, Kogi State University, Anyigba, Nigeria
}

Email address:

machuba50@gmail.com

\section{To cite this article:}

Mathias A. Chuba. Transmission Mechanism from Money Supply to Inflation in Nigeria. Economics. Vol. 4, No. 6, 2015 , pp. 98-105. doi: $10.11648 /$ j.eco.20150406.11

\begin{abstract}
This paper seeks to establish the transmission mechanism from money supply to inflation in Nigeria in order to resolve the controversy of whether money supply or interest rate should be a target of monetary policy. In doing this, a recursive vector autoregression (VAR) model is employed using data from first quarter 2000 to fourth quarter 2013. The response of CPI to money supply ranges from zero to 0.014 . The response of interest rate to money supply ranges from -0.094 to 0.021 . The response of exchange rate to CPI ranges from -0.007 to 0.013 . The response of exchange rate to interest rate ranges from -0.004 to 0.003 . The response of CPI to exchange rate ranges from -0.002 to 0.010 . The positive and significant responses of CPI to money supply and exchange rate to CPI indicate that the impact of the change in money supply is transmitted to inflation in Nigeria through the money-price link. The insignificant response of exchange rate to interest rate shows that the impact of the change in money supply is not transmitted to inflation in Nigeria through the money-interest link. The target of monetary policy should be the money supply and not interest rate.
\end{abstract}

Keywords: Transmission Mechanism, Money Supply, Inflation, Impulse Response

\section{Introduction}

The reduction of money supply is the traditional means through which central banks fight, moderate or prevent inflation. This is based on the quantity theory of money that inflation is always and everywhere a monetary phenomenon. The quantity theory of money states that the change in the price level is directly and proportionately related with the change in money supply. The quantity theory of money is based on the belief that there is only one channel through which the impact of an increase in money supply is transmitted to inflation. Specifically, it is based on the perception that the impact of an increase in money supply is transmitted directly to inflation.

While one agrees that inflation is always and everywhere a monetary phenomenon, it is not true that there is only one channel through which the impact of an increase in money supply is transmitted to inflation. Besides the direct transmission mechanism from money supply to inflation, the change in money supply may be transmitted to inflation based on the purchasing power parity (PPP) or money supply and demand framework or both.

PPP states that the change in the nominal exchange rate is directly proportional to the change in the price level. PPP suggests that the nominal exchange rate is determined mainly by factors that influence the domestic price level. The money supply might be an important determinant of the price level, and therefore could be an indirect factor in influencing the exchange rate.PPP indicates that a 10 percent increase in money supply leads to a 10 percent increase in prices, and 10 percent deprecation in the exchange rate.As exchange rate depreciates, inflation increases. The quantity theory of money and PPP suggest that the impact of the change in money supply is transmitted to inflation through the money-price link.

On the other hand, the money supply and demand framework shows how the change in money supply is transmitted to inflation through the money-interest link. Based on this framework, the rise in money supply causes a fall in domestic interest rate. A fall in interest rate causes depreciation of exchange rate, increasing domestic inflation.

For the economists that believe that the impact of the change in money supply is transmitted to inflation through the money-interest link are of the view that the central banks should focus their attention on controlling interest rate. On the other hand, economists that believe that the impact of the change in money supply is transmitted to inflation through the money-price link are of the view that the central banks 
should direct their attention on controlling money supply growth. This is part of a continuing controversy about what should be the target of monetary policy. In order to resolve this controversy, this paper seeks to establish the transmission mechanism from money supply to inflation in Nigeria.

The paper consists of seven sections. The next section is literature review. Section 3 presents the methodology. The results are discussed in section 4 and section 5 concludes. Section 6 gives an account of the strengths and weaknesses of the work and section 7 provides suggestions for further studies.

\section{Literature Review}

The quantity theory of money was formulated by Friedman (1956) and he states that aggregate prices $(\mathrm{P})$ and total money supply $(\mathrm{M})$ are related according to the equation $\mathrm{P}=\mathrm{MV} / \mathrm{Y}$, where $\mathrm{Y}$ is real output and $\mathrm{V}$ is velocity of money. The assumption that $\mathrm{Y}$ and $\mathrm{V}$ are constants implies that a given change in the rate of money growth induces an equal change in the inflation rate, prompting Friedman to claim that inflation is always and everywhere a monetary phenomenon. Many empirical studies on money supply and inflation relationship have been conducted but have come up with varied results.

Bozkurt (2014) examines money, inflation and growth relationship in Turkey by using co-integration test. For this purpose, quarterly data of money supply (M2), GDP, velocity of money and deflator are used for the period of 1999:2 2012:2. According to the results from this paper, money supply and velocity of money are the main determinants of inflation in the long run in Turkey. On the other hand, $1 \%$ decreases in income directly reduces inflation by $1 \%$.

Koyuncu (2014) uses the time-series approach to investigate the impact of budget deficit and money supply on inflation in Turkey for the period of 1987-2013. He finds that while there is no causality from inflation to money supply, there is causality from money supply to inflation in Turkey.

Al-Fawwaz and Al-Sawai'e (2012) analyze the short run relationship between money, the price, and the gross domestic product (GDP) growth for the Jordanian economy. Time series methods are used for the annual data for the period 1976-2009. The result indicates that there is a causal relationship from money supply to inflation, with low degree of 0.21 .

Mbongo, Mutasa and Msigwa (2014) examine the effects of money supply on inflation in Tanzania. The study applies OLS, VAR and ECM techniques to examine the effect of selected variables on inflation in Tanzania. OLS and ECM results show that money supply and exchange rate have significant impact on inflation in the short and long run. The VAR findings indicate that the current inflation can be influenced by the past state inflation.

Abate and Nandeeswara (2015) show the causality effect between money supply growth and price level in Ethiopia using a co-integrated vector auto regressive (VAR) model over the period 1975 to 2012. To explore the short-run direction of causality between money supply and consumer price index (CPI), Granger causality test has been applied and in order to investigate the existence of long-run relationship, co-integration analysis has been employed. The causation runs from money supply to prices, but price level does not causes money supply. The co- integration analysis established that money supply and CPI are found to be cointegrated suggesting an existence of long-run relationship.

Ahmed and Suliman (2011) examine the long-run relationships between real gross domestic product (GDP), money supply (MS) and price level (CPI)) for the Sudan economy using annual data for the period of 1960 to 2005 . To explore the short-run direction of causality between GDP, MS and CPI, Granger causality test has been applied and in order to investigate the existence of long-run relationship, cointegration analysis has been employed. The causation runs from money supply to prices, but price level does not causes money supply. The co-integration analysis established that the real GDP, money supply and CPI are found to be cointegrated suggesting an existence of long-run relationship.

Mbutor (2014) determines the exact portion of the changes that occur in aggregate prices that could be attributed exclusively to the growth in money supply in Nigeria for the period of 1970 to 2012 . The gross domestic product, nominal exchange rate, and the maximum lending rate are control variables, while inflation, proxy by the consumer price index and broad money supply are focus variables. All variables enter in logarithm forms, except interest rate. The impulse response function shows a persistent positive relationship between inflation and money supply. The variance decomposition of inflation shows that money supply accounts for up to 34.5 percent of aggregate price changes until the tenth period.

Olorunfemi and Adeleke (2013) examine money supply and inflation rate in Nigeria for the period of 1970-2008. The study uses vector auto regressive (VAR) model. Results from the causality test indicate that there exists a unidirectional causality between money supply and inflation rate. The causality test runs from money supply to inflation.

Umeora (2010) examines the effects of money supply (M2) and exchange rates on inflation in Nigeria for the period of 1982 to 2009 using annual data. The data are analyzed using multiple regression analysis (with SPSS). The results show that money supply and exchange rate have positive and negative effects on inflation in Nigeria respectively. The two variables account for only about $12 \%$ of the variation of inflation in Nigeria.

Odiba, Apeh and Daniel (2013) investigate the effect of money supply and aggregate demand on inflation in Nigeria for the period of 1986-2009. The data are analyzed using ordinary least square regression. The results show that money supply and aggregate demand are the main determinants of inflation in Nigeria during the review period.

Akinbobola (2012) aims at providing quantitative analysis of the dynamics of money supply, exchange rate and inflation in Nigeria. The sample covers quarterly data from 1986:01 to 
2008:04. The model was estimated using vector error correction mechanism (VECM). The empirical results show that in the long run, money supply and exchange rate have significant inverse effects on inflationary pressure in Nigeria.

Omanukwe (2010) examines the modern quantity theory of money using quarterly time series data in Nigeria for the period 1990:1-2008:4. The Granger causality is used to examine the causality between money and prices. The result shows the weak unidirectional causality from money supply to core consumer prices in Nigeria.

Adesoye (2012) examines the co-integration causality between prices, monetary aggregate and real output in Nigeria from the period 1970 to 2009 using the inflationary gap model that emanates from the quantity theory of money. The causality is found to significantly run from money supply to price. The econometric findings suggest that inflation in Nigeria is a monetary phenomenon.

The models specified by previous researchers do not include the various channels through which the impact of a change in money supply is transmitted to inflation. So, could not establish whether the monetary policy shock is transmitted to inflation through money-price link or through money- interest link or both. This paper contributes to the existing literature by establishing the channel through which the impact of the change in money supply is transmitted to inflation in Nigeria.

\section{Methodology}

\subsection{Theoretical Framework of the Study}

The quantity theory of money, the purchasing power parity and the money supply and demand framework show how the monetary policy shocks are transmitted to inflation. If the money stock rises without a corresponding increase in output, the additional money supply will simply bid up prices based on the quantity theory of money. As the price level rises, the exchange rate depreciates based on the purchasing power parity theory (Chamberlin and Yueh, 2006).

Given the demand for money, the rise in money supply causes a fall in domestic interest rate. The fall in domestic interest rate leads to an increase outflow of short-term finance from the country and a reduce inflow, as depositors seek to take advantage of relatively higher interest rate abroad. The supply of the domestic currency on the foreign exchange market rises and the demand falls. This causes a depreciation of the exchange rate (assuming the authorities allow it) [Sloman, 2006].

Thus, the monetary policy shocks may be transmitted to exchange rate through the price channel or interest rate channel or both. Consequently, this study adopts an approach in which these two channels of the transmission mechanism from money supply to exchange rate are hybridized. As such, the following specification of the VAR which reveals both simultaneity and interaction among the variables that are closely related to exchange rate and inflation can be stated as in equation (1).

$$
\text { (CPI, MSP, INTR, EXCHR) }
$$

Where: $\mathrm{CPI}=$ consumer price index representing inflation, MSP is money supply,

INTR = interest rate and EXCHR is exchange rate.

In order to establish the transmission mechanism from exchange rate to inflation, this study complements the quantity theory of money, the purchasing power parity theory and the money supply and demand framework with the demand pull and cost push theories of inflation. On demand pull theory of inflation, the depreciation of the exchange rate causes a rise in demand for exports, since they are now cheaper for people abroad to buy. It also causes a fall in demand for imports, since they are now more expensive. The rise in exports and a fall in imports will lead to an increase in net exports and aggregate demand and will cause a multiplied rise in national income (Sloman, 2006). But, in a short run, faster real growth may be associated with more rapid inflation. Often, this is because strong growth is the result of a rise in aggregate demand that causes real output to increase at the same time as it bids up prices (Tabi and Ondoa, 2011). Based on the demand pull theory of inflation, the net exports (NEXP) that is also closely related to exchange rate and inflation is included in the VAR model as specified in equation (2).

$$
\text { (CPI, MSP, INTR, EXCHR, NEXP) }
$$

In the system of floating exchange rates, exchange rates fluctuations can have a strong impact on the level of prices through the aggregate demand and aggregate supply. On the aggregate supply, depreciation (devaluation) of domestic currency can affect the price level directly through imported goods that domestic consumers pay. However, this condition occurs if the country is the recipient countries of international prices (international price taker). Non direct influence from the depreciation (devaluation) of currency against the price level of a country can be seen from the price of capital goods (intermediate goods) imported by the manufacturers as inputs. The weakening of exchange rate will cause the price of inputs more expensive, thus contributing to a higher cost of production. Manufacturers will certainly increase the cost to the price of goods that will be paid by consumers. As a result, the price level aggregate in the country increases or if it continues it will cause inflation (Achani, Fauzi and Abdullah, 2010). That is as exchange rate depreciates, the import price index increases and an increase in import price index will lead to an increase in producer price index. The increase in producer price index will lead to an increase in wholesale and retail price index and an increase in wholesale and retail price index will lead to an increase in consumer price index.Based on the cost-push theory of inflation, the import price index, producer price index, and wholesale and retail price index that are related to exchange rate and consumer price index are also included in the model as follows:

$$
\text { (CPI, MSP, INTR, EXCHR, NEXP, IPI, PPI, WRPI) }
$$

Where: IPI is import price index, PPI is producer price 
index, WRPI is wholesale and retail price index and all other variables are as previously defined.

\subsection{Model Specification}

This paper uses an eight variable vector autoregression (VAR) approach following Mbutor (2014) to determine the proportion of the change in the price level that can be attributed to the growth in money supply. The model is summarized in the reduced-form VAR:

$$
\mathrm{Y}_{\mathrm{t}}=\alpha_{0}+\sum_{\mathrm{i}=1}^{\mathbf{n}} \beta_{\mathrm{i}} \mathrm{Y}_{\mathrm{t}-\mathrm{i}}+\mathrm{U}_{\mathrm{t}}
$$

Where Yt is a $8 * 1$ vector of variables (CPI, MSP, INTR, EXCHR, NEXP, IPI, PPI, and WRPI,); $\beta \mathrm{i}$ are coefficient matrices of size $8 \times 8$ and $U_{t}$ is the one-step ahead prediction error with variance-covariance matrix $\Sigma, \alpha o$ is the intercept. The $t$ is time and $i$ is the lag length.

The VAR methodology deals with several endogenous variables together. But each endogenous variable is explained by its lagged, or past, values and the lagged values of all other endogenous variables in the model; usually, there are no exogenous variables in the model.

Since there are eight variables, the VAR technique is employed because it is very useful in dealing with multivariable causality. Forecasting is an important part of econometric analysis, for some people probably the most important. Vector autoregression has become quite popular method of forecasting economic variables.

As in any standard VAR model analysis, the way the variables enter the model is extremely important for the interpretation of the results. The most appropriate ordering is: CPI - MSP - INTR - EXCHR - NEXP - IPI - PPI - WRPI. The level of CPI has great influence on the amount of money supply. Money supply affects exchange rate indirectly through CPI channel. So, CPI or money supply should come first in the VAR. Money supply affects the exchange rate, possibly indirectly through the interest rate channel. The exchange rate may affect CPI directly. The exchange rate may also affect CPI indirectly through an increase in net exports and aggregate demand or through an increase in import price index, producer price index, and wholesale and retail price index.

\subsection{Estimation Method}

The VAR model is estimated using e-view 7.0. The time series properties of the data are analyzed using the Augmented Dickey-Fuller (ADF) unit root test of Dickey and Fuller (1979). Test of co-integration are carried out using the Johansen (1988) maximum likelihood procedure. The lag length is to be determined by the likelihood ratio (LR), final prediction error (FPE), Akaike information criteria (AIC), Schwarz information criteria (SC), and Hannan-Quinn information criteria (HQ). The VAR residual portmanteau tests for autocorrelations are used to verify the assumption of no autocorrelation. The inverse roots of autoregressive (AR) characteristic polynomial and VAR residual normality tests are used to verify whether the VAR model satisfy the stability and normality assumptions respectively.

\subsection{Data}

The empirical analysis is conducted using quarterly data. The time span covered is first quarter 2000 to fourth quarter 2013. The choice of 2000 as the base year is due to the fact that the data of import price index can only be obtained from that year.

The Consumer price index (CPI) of November 2009=100 is used as a measure of inflation. The quarterly data of narrow money supply $\left(\mathrm{M}_{1}\right)$ is chosen as the measure of money supply rather than broad money supply $\left(\mathrm{M}_{2}\right)$, as $\mathrm{M}_{2}$ includes foreign currency deposits and is therefore, more difficult for monetary authorities to control. The treasury bill rates (average discount rates on 3-month instruments) is the interest rate which is used to reflect changes in the Central Bank's behaviour. Exchange rate data are weighted average nominal exchange rate of the naira per unit of U.S. dollar. The U.S. dollar is used since it is the currency of Nigeria's major trading partner. The annual data of net exports are interpolated into quarterly data series using E-view. The quadratic-match average method of data processing is selected in interpolation. The import commodity price index of January $2007=100$ is used as import price index. An average implicit price deflator for agricultural and industrial goods and services is used as a measure of producer price index. Implicit price deflator for wholesale and retail trade is used as a measure of wholesale and retail price index.

LMSP
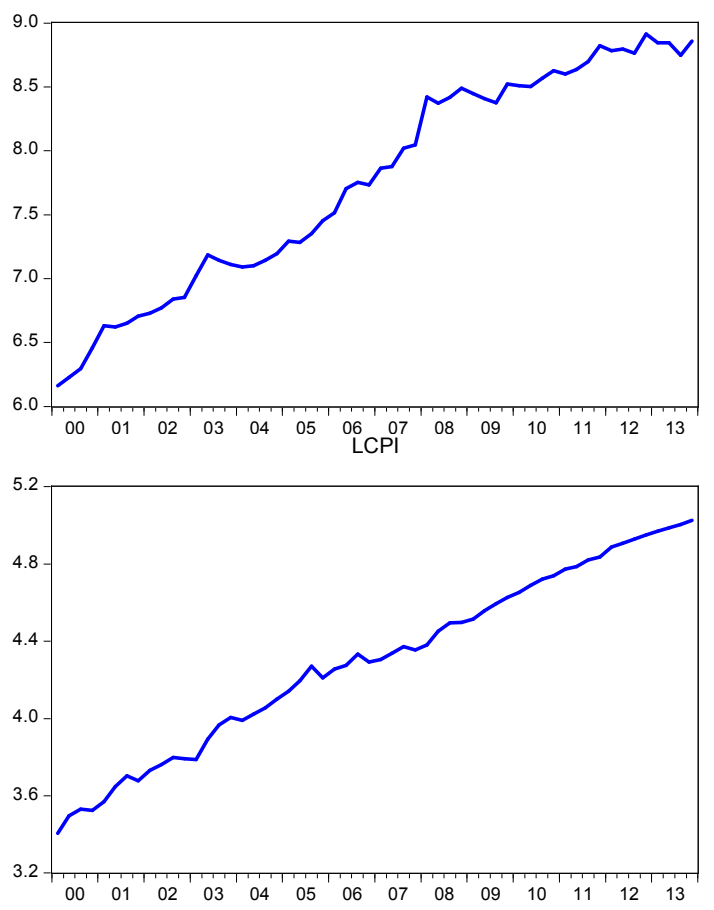

Figure 1. Logarithms of Money Supply and Consumer Price Index.

The interest rate data are obtained from various publications of Central Bank of Nigeria (CBN) Statistical 
Bulletin. The data for other variables are obtained from CBN Statistical Bulletin (December, 2013 online edition: www.cbn.gov.ng). The data of all the variables are transformed to logarithms in order to be of the same standard. A plot of the logarithms of money supply and CPI is shown in Figure 1. From Figure 1, the money supply and CPI have shown a general upward trend for most of the periods.

\section{Results}

\subsection{Unit Root Test and Co-integration Analysis}

The ADF test indicates that the logs of the variables are of different order of integration (zero, one and two) at $5 \%$ level of significance (Table 1). So, the co-integration test procedure is conducted. Table 2 reports the results of the Johansen test. Both the trace and maximum eigenvalue tests denote rejection of no co-integration at $5 \%$ level.

Table 1. Augmented Dickey-Fuller Test.

\begin{tabular}{|c|c|c|c|c|c|c|c|}
\hline \multirow[t]{2}{*}{ Variables } & \multirow{2}{*}{$\begin{array}{l}\text { Levels } \\
\text { ADF-Statistic }\end{array}$} & \multicolumn{3}{|c|}{ First Differences } & \multicolumn{2}{|c|}{ Second Differences } & \multirow[t]{2}{*}{ Order of Integration } \\
\hline & & Prob $^{*}$ & ADF-Statistic & Prob $^{*}$ & ADF-Statistic & Prob* & \\
\hline LMSP & -1.571 & 0.792 & -8.376 & 0.000 & - & - & $\mathrm{I}(1)$ \\
\hline LINTR & -2.879 & 0.117 & -7.991 & 0.000 & - & - & $\mathrm{I}(1)$ \\
\hline LEXCHR & -2.561 & 0.299 & -5.399 & 0.000 & - & - & $\mathrm{I}(1)$ \\
\hline LNEXP & -2.482 & 0.335 & -3.282 & 0.080 & -8.272 & 0.000 & $\mathrm{I}(2)$ \\
\hline LIPI & -3.694 & 0.031 & -9.509 & 0.000 & - & - & $\mathrm{I}(0)$ \\
\hline LPPI & -1.524 & 0.807 & -2.118 & 0.523 & -7.163 & 0.000 & $\mathrm{I}(2)$ \\
\hline LCPI & -3.381 & 0.065 & -7.405 & 0.000 & - & - & $\mathrm{I}(1)$ \\
\hline
\end{tabular}

Test critical values: $1 \%-4.166$

$5 \%-3.059$

$10 \%-3.184$

*MacKinnon (1996) one sided $\rho$-values

Source: Author's Computation.

Table 2. Johansen Test for Co-integration Vectors.

\begin{tabular}{llllll}
\hline Hypothesized No. of CE(s) & $\begin{array}{l}\text { Trace } \\
\text { Trace Statistic }\end{array}$ & $\mathbf{0 . 0 5}$ Critical Value & Prob** & $\begin{array}{l}\text { Maximum Eigenvalue } \\
\text { Max-Eigen Statistic }\end{array}$ & $\begin{array}{c}\text { 0.05 critical value } \\
\text { Prob** }\end{array}$ \\
\hline None* & 393.925 & 159.530 & 0.000 & 139.646 & 52.363 \\
At most 1* & 254.279 & 125.615 & 0.000 & 77.574 & 0.000 \\
At most 2* & 176.704 & 95.754 & 0.000 & 49.041 & 0.000 \\
At most 3* & 127.663 & 69.819 & 0.000 & 45.499 & 0.004 \\
At most 4* & 82.164 & 47.856 & 0.000 & 33.384 & 231 \\
At most 5* & 48.780 & 29.797 & 0.000 & 22.253 & 0.001 \\
At most 6* & 26.526 & 15.495 & 0.001 & 19.490 & 0.008 \\
At most 7* & 7.036 & 3.841 & 0.008 & 7.036 & 0.035 \\
\hline
\end{tabular}

*denotes rejection of the hypothesis at the 0.05 level

**MacKinnon-Haug-Michelis (1999) $\rho$-values

Source: Author's Computation.

\subsection{Vector Autoregression (VAR) Estimation}

The results of the lag length selection presented in Table 3 reveals that all the five criteria except Schwarz information criterion (SC) indicate 4 lags as the optimal model. Since the logs of the variables are co-integrated, the VAR is estimated in log level with 4 lags based on Akaike information criterion (AIC).

Table 3. VAR Lag Order Selection.

\begin{tabular}{llllll}
\hline Lag & LR & FPE & AIC & SC & HQ \\
\hline 0 & NA & $5.36 \mathrm{e}-12$ & -3.250 & -2.958 & -3.137 \\
1 & 620.585 & $7.78 \mathrm{e}-17$ & -14.414 & $-11.817 *$ & -13.397 \\
2 & 127.996 & $3.08 \mathrm{e}-17$ & -15.494 & -10.485 & -13.562 \\
3 & 107.043 & $1.25 \mathrm{e}-17$ & -16.866 & -9.431 & -14.007 \\
4 & $105.589 *$ & $1.64 \mathrm{e}-18 *$ & $-20.081^{*}$ & -10.175 & $-16.283^{*}$ \\
\hline
\end{tabular}

*indicates lag order selected by the criterion

Source: Author's Computation.

\subsection{Diagnostic Tests}

A battery of tests was conducted to evaluate the statistical properties of the model. The VAR residual portmanteau tests for autocorrelations shows that the residuals of the VAR model are not correlated. The inverse roots of autoregressive (AR) characteristic polynomial show that at least, one root is equal to 1 which indicates that the VAR model is unstable. However, the VAR model satisfies the normality condition. Having satisfied to some extent the statistical prerequisites, impulse response functions are used to establish the transmission mechanism from money supply to inflation in Nigeria.

\subsection{Impulse Response Analysis}

The Figure 2 shows the response of variables to monetary policy shocks. The figure 2(a) displays the response of $\log$ consumer price index (LCPI) to log money supply. The 
response of CPI to money supply ranges from zero to 0.014 during the ten periods. The CPI responds positively and significantly with the change in money supply in line with the quantity theory of money that the price level changes directly and proportionately with the change in money supply. The Figure 2(b) presents the response of log interest rate to log money supply. The response of interest rate to money supply ranges from -0.094 to 0.021 during the ten periods. In line with the supply and demand of money framework, interest rate falls as money supply increases.

The Figure 3 presents the response of exchange rate to variables shocks. The Figure 3(a) presents the response of log exchange rate to LCPI. The response of exchange rate to CPI ranges from -0.007 to 0.013 during the ten periods. The positive and significant response of exchange rate to CPI is in

\section{Response of LCPI to LMSP}

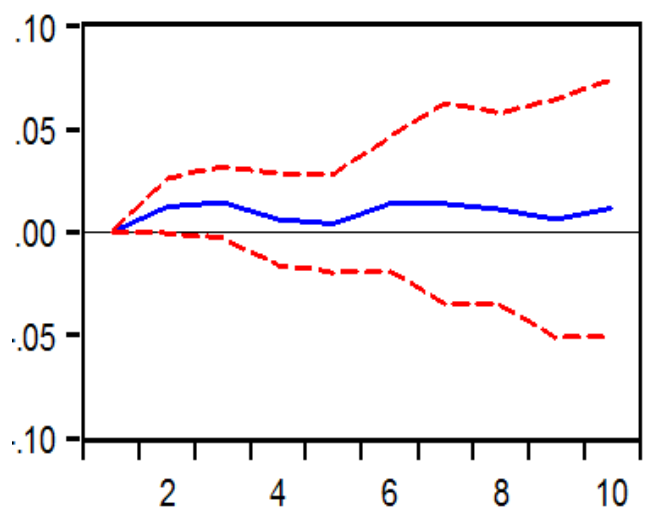

(a) line with the purchasing power parity that the change in the nominal exchange rate is directly proportional to the change in the price level. The positive and significant responses of CPI to money supply and exchange rate to CPI indicate that the impact of monetary policy shocks is transmitted to exchange rate through the money-price link. The Figure 3(b) shows the response of log exchange rate to log interest rate. The response of exchange rate to interest rate ranges from 0.004 to 0.003 during the ten periods. This result shows that interest rate does not have any influence on exchange rate. This is because with rising exchange rate, the monetary authority raises interest rate to prevent it depreciating further. This result indicates that the impact of monetary policy shock is not transmitted to exchange rate through the moneyinterest link.

\section{Response of LINTR to LMSP}

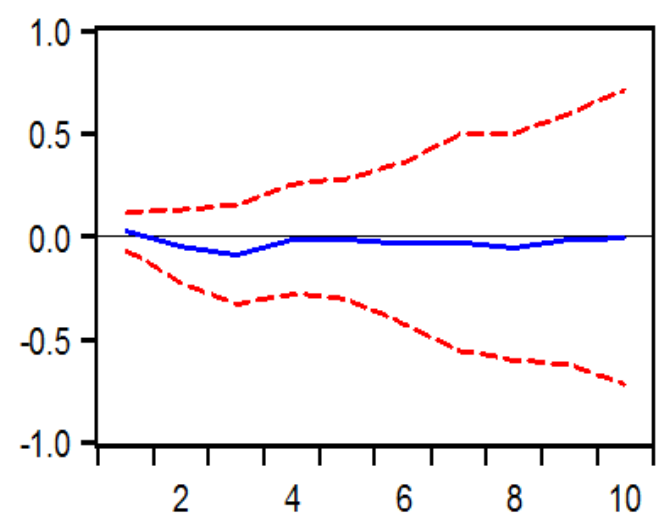

(b)

Figure 2. Response of Variables to Monetary Policy Shock.

\section{Response of LEXCHR to LCPI}

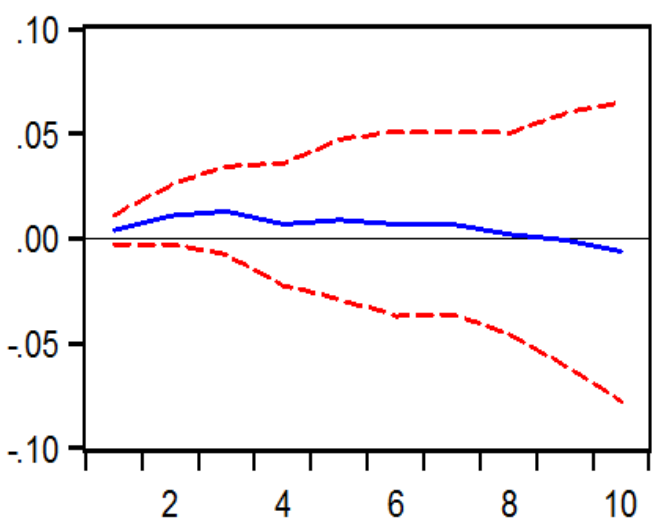

(a)

\section{Response of LEXCHR to LINTR}

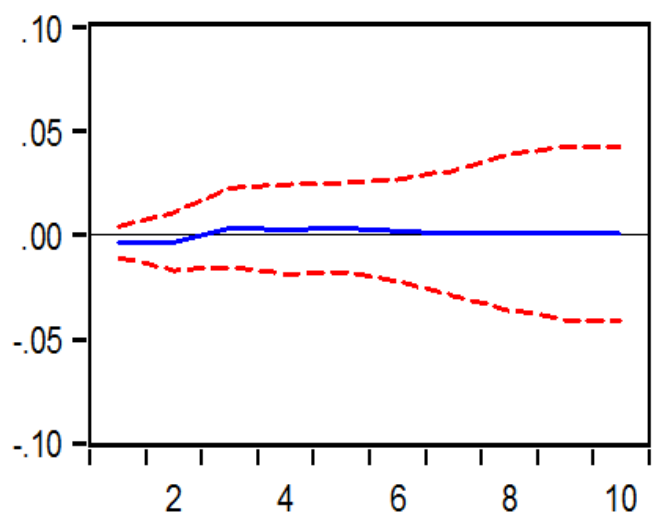

(b)

Figure 3. Response of Exchange Rate to Variables Shocks.

The Figure 4 shows the response of CPI to exchange rate. The response of CPI to exchange rate ranges from -0.002 to 0.010 during the ten periods. The positive response of CPI to exchange rate shows that exchange rate depreciation is transmitted directly to CPI through a decrease in the consumer goods and services that are supplied from foreign countries. 


\section{Response of LCPI to LEXCHR}

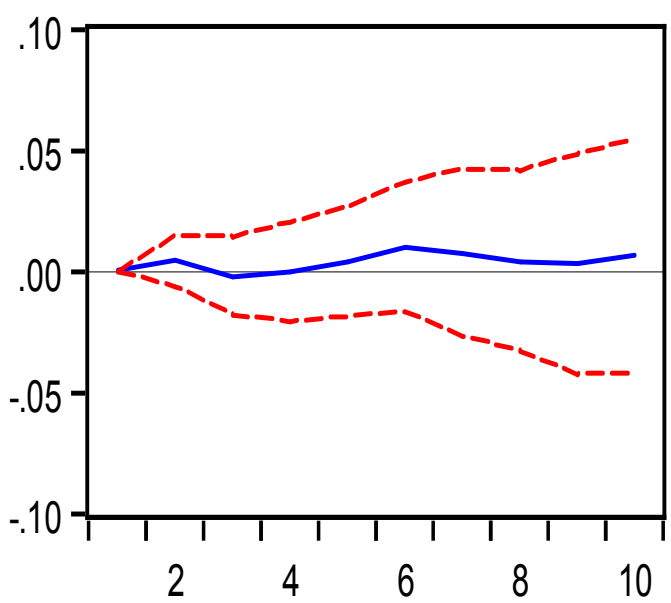

Figure 4. Response of Consumer Price Index to Exchange Rate.

\section{Conclusions}

The response of CPI to money supply ranges from zero to 0.014. The response of interest rate to money supply ranges from -0.094 to 0.021 . The response of exchange rate to CPI ranges from -0.007 to 0.013 . The response of exchange rate to interest rate ranges from -0.004 to 0.003 . The response of CPI to exchange rate ranges from -0.002 to 0.010 .

The positive and significant responses of CPI to money supply and exchange rate to CPI indicate that the impact of the change in money supply is transmitted to inflation in Nigeria through the money-price link. The insignificant response of exchange rate to interest rate shows that the impact of the change in money supply is not transmitted to inflation in Nigeria through the money-interest link. Therefore, the target of monetary policy in Nigeria should be the money supply and not interest rate.

\section{Strengths and Weaknesses of the Work}

A supply shock, demand shock and external shock together with domestic price indices are employed in a recursive VAR framework. A VAR model is useful in allowing for endogenous interactions between the money supply and other macroeconomic variables. With the use of VAR model, this paper was able to establish the transmission mechanism from money supply to inflation in Nigeria. The paper shows that in order to achieve price stability, the Central Bank of Nigeria should direct its attention on controlling the size of money supply and not on controlling interest rate.

However,this paper does not capture the Keynesian view on the transmission mechanism from money supply to inflation. In the typical Keynesian analysis, a change in money supply affects output and prices through the interest rate. For example, the central bank can increase the money supply and drive down interest rate. At lower interest rate, a greater level of investment is forthcoming, driving up total planned expenditure. Higher total expenditure causes demand-pull inflation. By the time the Keynesian view on the transmission mechanism from money supply to inflation is included in the model that is used for this study, the conclusions may be different.

\section{Suggestions for Further Studies}

In order to capture the Keynesian view on the transmission mechanism from money supply to inflation, gross domestic investment (GDI) should be included in the model and the impulse responses of interest rate to money supply, GDI to interest rate and CPI to GDI should be estimated and analyzed.

\section{References}

[1] Abate E. and R. P. Nandeeswara (2015), "A Co-integration Analysis of Money Supply and Price in Ethiopia", International Journal of Recent Scientific Research, Vol. 6, Issue, 5, pp.3972-3979.

[2] Achsani,N. A.; A. J. F.A. Fauzi and P. Abdullah (2010), "The Relationship between Inflation and Real Exchange Rate: Comparative Study between ASEAN+3, the EU and North America", European Journal of Economics, Finance and Administrative Sciences - Issue 18, 69 - 76 .

[3] Adesoye, A. B. (2012), "Price, Money and Output in Nigeria: A Cointegration-Causality Analysis", African Journal of Scientific Research, Vol. 8, No. 1.

[4] Ahmed, A. E. M. and S. Z. Suliman (2011), “The Long- Run Relationship Between Money Supply, Real GDP, and Price Level: Empirical Evidence from Sudan", Journal of Business Studies Quarterly, Vol. 2, No. 2, pp. 68-79.

[5] Akinbobola T. O. (2012), "The Dynamics of Money Supply, Exchange Rate and Inflation in Nigeria", Journal of Applied Finance and Banking, Vol. 2, No. 4, 117 - 141, Scienpress Ltd.

[6] Al-Fawwaz T. M. and K. M. Al-Sawai'e (2012), “Output, Money, and Prices: The Case of Jordan", International Business Research,Vol. 5, No. 12, Canadian Center of Science and Education.

[7] Bozkurt C. (2014), "Money, Inflation and Growth Relationship: The Turkish Case", International Journal of Economics and Financial Issues, Vol. 4, No. 2, pp. 309-322.

[8] Chamberlin, G. and L. Yueh (2006), Macroeconomics, UK: Thompson Learning.

[9] Dickey, D. A. and W. A. Fuller (1979), "Distribution of the Estimators for Autoregressive Time Series with a Unit Root", Journal of the American Statistical Association, 74, p. 427-431.

[10] Friedman, M. (1956), Studies in the Quantity Theory of Money, University of Chicago Press, Chicago.

[11] Friedman, M. (1956), The Quantity Theory of Money: A Restatement, In Friedman, M. (Ed.), Studies In the Quantity Theory of Money, University of Chicago Press, Chicago.

[12] Johansen, S. (1988), "Statistical Analysis of Co-integrating Vectors", Journal of Economic Dynamics and Control, 12, pp. 231-54. 
[13] Koyuncu F. T. (2014), "Causality Network between Budget Deficit, Money Supply and Inflation: An Application to Turkey”, International Journal of Business and Social Science Vol. 5, No. 10(1), Center for Promoting Ideas, USA.

[14] Mbongo J. E.; F. Mutasa and R. E. Msigwa (2014), "The Effects of Money Supply on Inflation in Tanzania", Economics, 3(2): 19-26, Science Publishing Group.

[15] Mbutor O. M. (2014), "Inflation in Nigeria: How Much is the Function of Money?", Journal of Economics and International Finance, Vol. 6(1), pp. 21 - 27.

[16] Odiba E. O.; A. S. Apeh and E. J. Daniel (2013), "Money Supply and Inflation in Nigeria, 1986-2009", Journal of Business and Organizational Development,Volume 5, Number 1.

[17] Olorunfemi S. and P. Adeleke (2013), "Money Supply and Inflation in Nigeria: Implications for National Development", Modern Economy, 4, 161-170, Scientific Research.
[18] Omanukwue P. N. (2010), "The Quantity Theory of Money: Evidence from Nigeria", Central Bank of Nigeria Economic and Financial Review, Volume 48/2.

[19] Sloman, J. (2006), Economics, Sixth Edition, UK: Pearson Education Limited.

[20] Tabi, H. N. and H. A. Ondoa (2011), "Inflation, Money and Economic Growth in Cameroon", International Journal of Financial Research, Vol. 2, No. 1, March, www.sciedu.ca/ijfr.

[21] Umeora, C. E. (2010), "Effects of Money Supply and Exchange Rates on Inflation in Nigeria", Journal of Management and Corporate Governance, Volume 2, Cenresin Publications. 